\title{
VIBRANT MATTER \\ POSTHUMANISM AS AN ETHICS OF RADICAL ALTERITY
}

\section{MATÉRIA VIBRANTE \\ O PÓS-HUMANISMO ENQUANTO ÉTICA DE UMA ALTERIDADE RADICAL}

RICARDO GIL SOEIRO*

ricardogilsoeiro@campus.ul.pt

The present article wishes to present critical posthumanism as an ethics of radical alterity. It is divided into three explanatory moments: firstly, it provides a set of perfunctory remarks on the interdisciplinary field of posthumanism; it will then proceed to a general overview of Rosi Braidotti's The Posthuman (2013); finally, a brief case-study analysis of W. Szymborska's poetry will be conducted, thus hoping to show how posthumanist theory can illuminate literary texts and, indeed, how these can, in turn, prompt a reassessment of posthumanist theory.

Keywords: alterity; Braidotti, Rosi; critical posthumanism; Szymborska, W.

O presente texto apresenta uma leitura do pós-humanismo crítico enquanto ética de uma alteridade radical. A análise em apreço encontra-se estruturada em três momentos distintos: em primeiro lugar, procurar-se-á explicitar alguns tópicos decorrentes do campo interdisciplinar do póshumanismo; de seguida, apresentar-se-á uma leitura sinóptica da obra The Posthuman (2013), de Rosi Braidotti; por fim, conduzir-se-á um breve estudo de caso em torno da poesia de W. Szymborska, procurando equacionar de que forma a teoria pós-humanista se revela passível de iluminar os objectos literários e de como, por seu turno, estes são capazes de desencadear uma reavaliação da teoria pós-humanista.

Palavras-chave: alteridade; Braidotti, Rosi; pós-humanismo crítico; Szymborska, W.

Data de receção: 2020-05-13

Data de aceitação: 2020-09-01

DOI: $\underline{10.21814 / 2 i .2650}$

\footnotetext{
* Assistant Professor at the Department of German Studies of the School of Arts and Humanities, and research fellow at the Center for Comparative Studies, University of Lisbon, Portugal. ORCID: 0000-00030281-6014.
} 


\section{Introductory remarks}

What does it mean to be post-human? What does it mean to think beyond humanism? Is it possible to craft a mode of philosophy, ethics, and interpretation that rejects the classic humanist divisions of self and other, mind and body, society and nature, human and animal, organic and technological? How is literature able to be used to shed light on the manifold processes through which posthumanist subjectivities are understood and enacted?

By providing a post-dualistic and a non-hierarchical standpoint to reflect upon issues as subjectivity, otherness, and ethics, the complex field of posthumanism (ranging from literary and cultural studies to animal studies, from media studies to deconstruction) addresses these very questions in an attempt to come to terms with one of the most pressing issues of our times. Such a multi-layered posthumanist approach offers a rethinking of far-reaching debates on the deconstruction of humanism, biopolitics, technology, and virtual reality.

As an interdisciplinary field of study and multifaceted critical discourse, posthumanism is a fairly recent body of thought. Even though posthumanism has stemmed from distinct lineages, it can be traced back to the anti-humanist bent of poststructuralism, which on its turn remains heir to Heidegger's and Nietzsche's philosophy. Mapping the terrain of these far-reaching debates will allow us to: understand the philosophical, political and cultural approach provided by the posthumanist vision, not shying away from multifaceted questions about the human in the age of technological modification and hybridized life forms; radically move beyond the traditional humanist worldview on the autonomous, self-willed individual agent towards an innovative view of the human itself as an assemblage, co-evolving alongside with other forms of life, enmeshed with the environment and technology; call for a radical rethinking of species uniqueness by upholding a multispecies citizenship; to fully comprehend the ways in which posthumanism, by virtue of its intrinsic transdisciplinary scope (merging seemingly disparate, yet complementary, scientific fields: animal studies, disability studies, monster studies, consciousness studies, techno-science studies, critical race studies), concurs to a re-shaping of the boundaries of the human.

Following on Freud's footsteps, Donna Haraway explains poignantly in her book, When Species Meet, how the three great wounds to the primary narcissism of the human (the Copernican revolution, the Darwinian theory of evolution, and the Freudian excavation of the unconscious) have seriously destabilized humanity's geographical, historical, and psychic self-centeredness. To these Haraway adds a fourth, "informatic or cyborgian" wound, "which infolds organic and technological flesh. As a result, the human has to think of her- or himself as always already technological, as co-constituted and coevolving with the world which is made up of animate and inanimate entities. To explain this performative process, Haraway takes recourse to the metaphor of dance and argues that this process of co-constitution is never fully stabilized or accomplished, and that each intervention, each movement, generates a new state of becoming. "All the dancers are redone through the patterns they enact," she writes $(2008$, p. 25).

Equally pivotal to the spirit of critical posthumanism is Deleuzean philosophy. Against the backdrop of the previous examination of the posthumanist approach (formulated on a post-anthropocentric and post-humanist episteme and based on decentralized and non-hierarchical modes of being-in-the-world), most of posthumanist thinking has progressed by feeding on the concept of "becoming", championed by 
Deleuze and Guattari. By replacing identity with difference and being with becoming, Deleuzian ontology provides the ground to think heterogeneity and inexhaustible noveltyproducing processes that underlie all phenomena. Deleuze's concept is indelibly attached to a non-anthropocentrism, putting forward that "Not man as the king of creation, but rather as the being who is in intimate contact with the profound life of all forms or all types of being, who he is responsible for even the stars and animal life" (Deleuze, 1977: 4-5. See also the chapter tellingly entitled "Becoming-Intense, Becoming-Animal, Becoming-Imperceptible", in A Thousand Plateaus).

We will try to establish in its full impact the implications of such a concept for the replacement of the exclusionary facet of anthropocentrism by a rethinking of the human self as an instantiation of a network of connections, exchanges, linkages, and crossings with all forms of life. A renewed understanding of the human self as being less about Being and more about a 'becoming-with", to use Haraway's phrasing in When Species Meet (2008). It should not go unmentioned that, far from signifying a fall into relativism or nihilistic defeatism, the posthumanist standpoint argues for a sustainable ethics for a non-unitary subject and proposes an enlarged sense of inter-connection between self and others (including the non-human others. Given the cutting-edge nature of posthumanist research, solid criticism of the field only emerged within the last two decades. Hayles' How We Became Posthuman (1999), inspired by Haraway's thought, was panoramic in scope and indeed pioneering in the way it succeeds in mapping the posthuman in the light of a semiotics of virtuality. Badmington's Posthumanism (2000) was the first anthology of theoretical texts on the subject, but so far it has not inspired similar efforts.

The subject is not taken up in any length until 4 years later when, following on the footsteps of Graham's Representations of the Post/Human, Badmington's Alien Chic (2004) explores the contamination of the human by its inhuman others, particularly in the representation of aliens in science fiction. Choosing a different methodological outlook, the work of Wolfe/Clarke has convincingly shown how cybernetics and systems theory provide an analogical framework for posthumanism. In 2012, a special issue on Posthumanist Subjectivities appeared in Subjectivity: whilst showcasing compelling contributions that re-evaluate the impact of poststructuralist thought on posthumanist subjectivities, it nevertheless falls short on alluding to the manifold implications that the present project seeks to address, namely the ways in which literary works in particular open up alternative ways of conceptualizing the human subject and its relationship to other modes of existence. In 2014, a special issue on European Posthumanism appeared in the EJES, ed. Herbrechter/Callus. But here too, even if fruitfully dis/locating European posthumanism, a literary standpoint is clearly missing, a different perspective which would otherwise bring to the fore potential trajectories of the posthuman. The last few years have witnessed insightful new work from 4 leading authors in the field: Wolfe's What is posthumanism (2009), Braidotti's The Posthuman (2013), Herbrechter's Posthumanism (2013), Nayar's Posthumanism (2014). But although these recent booklength contributions undoubtedly display the main merits of posthumanism, they nevertheless also manifest a deficient treatment of literary figurations of posthumanist subjectivities.

Of course there are notable exceptions, works that have been engaged in a careful analysis of the relationship between posthumanism and literature, namely: Wallace's D.H. Lawrence, Science and the Posthuman (2005), the collective vol. Cy-Borges (2009), Moore's Practicing the Posthumanities (2011), Thomsen's The New Human in Literature (2013) or the long-awaited The Cambridge Companion to Literature and the Posthuman, edited by Bruce Clarke and Manuela Rossini, which positions itself as one the most important tools of this field of study. However, it should not go unmentioned that within 
the last decade we have witnessed a deep-seated interest in the constellation of posthumanity, witnessing the proliferation of academic works and research projects on these matters. I draw your attention only to the project "Post-Human Aesthetics", promoted by the University of Aarhus, in Denmark, the foundation in 2017 of the Journal of Posthuman Studies (directed by Stefan Lorenz Sorgner), the book series "Beyond Humanism: Trans-and Posthumanism", published by Peter Lang or the recent creation of a number of international networks, such as the Critical Posthumanism Network or the Posthuman New York Group, actively contributing to the constitution of a vibrant intellectual community of posthumanism.

\section{Life Beyond Species: Rosi Braidotti's The Posthuman and the Post- Anthropocentric Turn}

Let us now turn our attention to Braidotti's The Posthuman (2013), one of the most influential studies on the topic of posthumanism. First of all, let me start off by alluding to the telling cover of the book. In the first chapter, she points out that "the allegedly abstract ideal of Man as a symbol of classical Humanity is very much a male of the species; it is a he. Moreover, he is white, European, handsome, and able-bodied" (Braidotti, 2013, p. 24). To counter monistic celebrations of Leonardo Da Vinci's Vitruvian Man as the pillar of the project of imagining Western Man, Braidotti puts forward the image of a "New Vitruvian Woman" (a digital artwork by Jim Downdalls), as an alternative to the representations of male embodiment. Throughout the book, Braidotti pursues a twofold aim: on the one hand, she addresses the question of what the posthuman might look like in a post-anthropocentric perspective while, at the same time, she tries to argue the case for a posthuman theory that takes into acount an intricate conceptualization of posthumanistic subjectivity. The discussion is, therefore, laid bare on two distinct, yet intertwined planes: it explores the extent to which a posthumanist move displaces the traditional humanistic unity of the subject, further arguing that this loss of self-mastery may indeed help us make sense of our flexible and multple identities.

Simultaneously, claiming the pioneering facet of the philosophical enterprise, Braidotti addresses the importance of devising new concepts, innovative conceptual tools that would aid us in thinking about the challenges of the posthuman condition. It is precisely at this juncture that this chapter weaves together these two dimensions. Mainly drawing upon Spinoza, Deleuze and Nietzsche, the tone of the essay is affirmative and, very much like Deleuze's unorthodox epistemology, Braidotti's level of analysis is not solely a question of intellectual understanding, but rather one of intensity and resonance, working as she clarifies in the conclusion "within the belly of the beast", that is to say, resisting the myth of organicism and holistic harmony, as well as what she calls capitalist opportunism. Her chief goal is clear: a more affirmative approach to the redefinition of posthuman subjectivity, as in the counter models of transversal, relational nomadic assemblages. In short, a fresh approach worthy of the complexities of our age, a nomadic zoe-centred approach that would be able to connect human to non-human life so as to develop a comprehensive eco-philosophy of becoming.

As already mentioned, one of her crucial points is the need to think differently, to think otherwise, by urging us to reassess our linguistic and conceptual tools. Here we cannot help but be reminded of Wittgenstein's famous analogy, in which language is compared to a bag of carpenter's tools, each with its own equipament, its own rules, its own criteria of success and failure; and, surely enough, new tools and new games can be added infinitely. Braidotti urges us, therefore, to be experimental and even transgressive. 
As she points out in the final page of this chapter: "As Deleuze and Guattari teach us, thinking is about the invention of new concepts and new productive ethical relations" (2013, p. 104). Deleuze conceived of philosophy as the production of concepts. In What is Philosophy?, Deleuze and Guattari second Nietzsche's view that philosophy should "invent modes of existence or possibilities of life" (1977, p. 72). To be sure, there is messianic overtones in their musings, when they claim that "the creation of concepts in itself calls for a future form, for a new earth and people that do not yet exist", aiming at "the constitution of an earth and a people that are lacking" (p. 108).

The making and remaking of concepts sets in motion a creative process, which is not reducible to a static recognition but demands a dynamic, experiential and experimental encounter that force us to construct meaning for a particular experience which is as yet presently unthought of and lacking sense. Against this background, Braidotti begins by embracing a Spinozian vitalist materialism, stating that: "raw cosmic energy that underscores the making of civilizations, societies and their subjects. Vitalist materialism is a concept that helps us make sense of that external dimension, which in fact enfolds within the subject as the internalized score of cosmic vibrations (Deleuze)" (pp. 55-56).

Questioning Descartes' philosophy and rejecting transcendentalism in favour of a "radical immanence", Braidotti proceeds to spell out Spinoza's monism, according to which matter, the world and the humans are not dualistic entities structured according to principles of internal or external opposition. Braidotti's rehabilitation of Spinozist monism (the unity of all living matter) will constitute an important tool for overcoming dialectical oppositions, thus engendering non-dialectical understandings of materialism itself. Calling for a post-anthropocentric turn, she makes plain that: "These monistic premises are for me the building blocks for a posthuman theory of subjectivity that does not rely on classical Humanism and carefully avoids anthropocentrism" (p. 56), and further adds: "In my view, there is a direct connection between monism, the unity of all living matter and post-anthropocentrism as a general frame of reference for contemporary subjectivity" (p. 57).

Since transdisciplinary complexifies the issue at hand, and since the neo-Spinozist approach is reinforced by new developments in the mind-body interrelation within the neural sciences, the key question for Braidotti is quite simply to ask: "what understandings of contemporary subjectivity and subject-formation are enabled by a postanthropocentric approach? What comes after the anthropocentric subject?" (p. 58). This issue is further complexified by the techno-scientific strutucture of contemporary global economy. Placing a strong emphasis on the biogenetic structure of contemporary capitalism, one of the major challenges consists in exploring the ways in which contemporary market economies profit from the control and commodification of all that lives, the commodification of Life by bio-genetic advanced capitalism.

These shifts and dislocations induced by globalized cultures and economies bring about important implications on subjectivity: "What happens to subjectivity in this complex field of forces and data flows? My argument is that it becomes an expanded relational self, engendered by the cumulative effect of all these factors" (p. 60). This premise is particularly meaningful, inasmuch as it paves the way for making a strong case for a non-unitary or nomadic conception of the subject. In truth, the author's lifelong engagement in the project of nomadic subjectivity is nicely encapsulated in the epigraph to her essay "Writing as a Nomadic Subject" (2014), which she borrows from Virgina Woolf's The Waves: "I am rooted but I flow", a poignant line which echoes througout some of her previous undertakins, namely: Nomadic Subjects. Embodiment and Sexual difference in Contemporary Feminist Theory (1994), and Transpositions: On Nomadic Ethics (2006). 
She proceeds by adding that the relational capacity of the posthuman subject is not confined within our species, but it includes all non-anthropomorphic elements, emphasizing the non-human, vital force of Life -zoe, as she labels it. She specifies it in the following manner: "Life', far from being codified as the exclusive property or the unalienable right of one species, the human, over all others or of being sacralized as a pre-established given, is posited as process, interactive and open-ended. This vitalist approach to living matter displaces the boundary between the portion of life - both organic and discursive - that has traditionally been reserved for anthropos, that is to say bios, and the wider scope of animal and non-human life, also known as zoe. Zoe as the dynamic, self-organizing structure of life itself [...] stands for generative vitality. It is the transversal force that cuts across and reconnects previously segregated species, categories and domains. Zoe-centred egalitarianism is, for me, the core of the post-anthropocentric turn: it is a materialist, secular, grounded and unsentimental response to the opportunistic trans-species commodification of Life that is the logic of advanced capitalism" (p. 60).

Braidotti picks up the initial thread she has left behind and comprehensively refutes the opportunistic political economy of bio-genetic capitalism that turns Life/zoe into a commodity for trade and profit. She criticizes the capitalization of living matter since the opportunistc political economy of bio-genetic capitalism downplays the distinction between the human and other species. Global economy is post-anthropocentric in that it ultimately unifies all species under the imperative of the market. Therefore, what is at stake here is a negative sort of cosmopolitan interconnection which is established through a pan-human bond of vulnerability.

She then goes on to argue: "The posthuman dimension of post-anthropocentrism can consequently be seen as a deconstructive move. What it deconstructs is species supremacy, but it also inflicts a blow to any lingering notion of human nature, anthropos and bios, as categorically distinct from the life of animals and non-humans, or zoe" (p. 65 ). The close link between posthumanism and deconstruction has been previously made clear by Neil Badmington in his essay "Theorizing Posthumanism":

To engage with humanism, to acknowledge its persistence, is not necessarily to support humanism. Derrida's call for critics to repeat "what is implicit in the founding concepts and the original problematic" is by no means a demand for a simple, straightforward repetition of those concepts. Deconstruction, rather, as he has insisted on various occasions, consists in repeating things "in a certain way," in order to expose the overwhelming uncertainty of even the most apparently certain discourses. If the version of posthumanism that I am trying to develop here repeats humanism, it does so in a certain way and with a view to the deconstruction of anthropocentric thought (Badmington, 2003, pp. 15-16).

In what remains of Braidotti's text, the chief purpose is to tackle "the productive aspects of the posthuman predicament" (Braidotti, 2013, p. 66), by opening up perspectives for affirmative transformations of both the structures of subjectivity and the production of theory and knowledge: these processes are labelled as "becoming-animal, becoming-earth and becoming-machine", drawing inspiration from Deleuze's and Guattari's philosophy.

The overriding goal is to displace the hierarquical, the dialectics of otherness and sovereignity. Influenced by the work of Derrida, Haraway and Cary Wolfe, Braidotti aims at a "displacement of anthropos", while placing a particular emphasis on empathy. According to Braidotti, the major challenge is "how to derritorialize, or nomadize, the human-animal interaction [...] The posthuman in the sense of post-anthropocentrism displaces the dialectal scheme of opposition, replacing well-established dualisms with the recognition of deep zoe-egalitarianism between humans and animals. The vitality of their bond is based on sharing this planet, territory or environment on terms that are no longer

REVISTA 2i, Vol. 2, N. ${ }^{\circ}$ 2, 2020, pp. 191-204. elSSN: 2184-7010 
so clearly hierarchical, nor self-evident. This vital interconnection posits a qualitative shift of the relationship away from species-ism and towards an ethical appreciation of what bodies (human, animal, others) can do. An ethology of forces based on Spinozist ethics emerges as the main point of reference for changing human-animal interaction" (pp. 71-72).

Her perspective is clear: the inter-relation human/animal is constitutive of the identity of each, it is thus a "transformative or symbiotic relation that hybridizes and alters the 'nature' of each one and foregrounds the middle grounds of their interaction" (p. 79). Once again asserting the "affirmative brand of posthuman thought" in that it challenges the sovereignity of Sameness, she contends that: "Intensive spaces of becoming have to be opened and, more importantly, to be kept open" (p. 80).

Subsequently Braidotti sheds light into "the Posthuman as Becoming-earth", addressing post-anthropocentric shift towards a planetary, geo-centred perspective. Urging us to develop a dynamic and sustainable notion of vitalist, self-organizing materiality, Braidotti's approach seeks to enlarge the frame and scope of subjectivity, and she does so by encompassing the idea of subjectivity as an assemblage that includes nonhuman agents which means that subjectivity is not the exclusive prerogative of anthropos: "we need to viualize the subject as a transversal entity encompassing the human, our genetic neighbours the animals and the earth as a whole" (p. 82).

The question of language and representation resurfaces yet another time: "we need to devise a new vocabulary, with new figurations to refer to the elements of our posthuman embodied and embedded subjectivity" (p.82). A need for conceptual creativity is stressed, a new scheme for rethinking posthuman subjectivity. In this regard, she even alludes to her own efforts in devising alternative figurations, namely the nomadic subject.

She calls for a radical post-anthropocentric framework: a way of updating critical theory for the third millennium, resisting all forms of residual anthropomorphic normativity. As we have seen, the stepping-stone for Braidotti is the proposal of an updated brand of Spinozism: "I see Spinozist monism, and the radical immanent forms of critique that rest upon it, as a democratic move that promotes a kind of ontological pacifism. [...] In my view, monistic relationality stresses the more compassionate aspect of subjectivity. A Spinozist approach, re-read with Deleuze and Guattari, allows us to bypass the pitfalls of binary thinking and to address the environmental question in its full complexity" (p. 86).

In this context, Braidotti refers to Deleuze's and Guattari's use of James Joyce's neologism 'chaosmos'. Joyce used the term to designate a "cosmos at the verge of chaos, one that is surging toward the exciting possibility of going out of existence, struggling onward at the edge of the existential abyss." (p. ) This concept it will play a major part in the thought of the Deleuze and Guattari who described art, philosophy and science as three distinct ways to plunge into chaos in an attempt to tame it.

One important note should not be overshadowed: by stressing the "radical" tone of posthumanism, Braidotti places the main focus in the critical dimension of posthumanism, so much so that her position sets itself apart from the more popular strand of posthumanism (best exemplified in cinema and pop culture, and cyberpunk fiction) which merely implies a hagiography of techno-modifications of the human, arguing that technological and biological modifications will improve the human (a sort of transhumanism which is presciently exposed by Wolfe as being a mere intensification of humanism). Contrary to this strand, Braidotti's post-anthropocentric shift away from the hierarchical relations that had privileged 'Man' requires a form of estrangement and a radical repositioning on the part of the subject" (p. 88), paving the way for "creative alternatives" (p. 89) and active deterritorializations which mirror policentric alterities. 
Braidotti wraps up her text with the posthuman as becoming-machine: "The posthuman predicament is such as to force a displacement of the lines of demarcation between structural differences, or ontological categories, for instance between the organic and the inorganic, the born and the manufactured, flesh and metal, electronic circuits and organic nervous systems" (p. 89).

She "sustains a vitalist ethics of mutual trans-species interdependence. It is a generalized ecology [...] which aims at crossing transversally the multiple layers of the subject, from interiority to exteriority and everything in between" (p. 92). This process is what she means by "post-anthropocentric posthumanism", an approach which is being advocated throughout the book and which is enshrined in the nomadic subject, combining non-unitary subjectivity with ethical accountability by foregrounding the ontological role played by relationality" (p. 93). "The subject is ontologically polyvocal", she summs it up neatly, whilst endorsing an incisive diagnosis of the implications for a posthuman politics that cherishes the transversality of relations and the ingenious "elaboration of alternative modes of transversal subjectivity" (p. 98).

Closing in the same affirmative vein, Braidotti praises the concept of difference, as it envisages an ontological relationality, a humbling experience of not-Oneness, central to the non-unitary subject that is anchored in an ethical bond to alterity: "I have stressed difference as the principle of not-One, that is to say as differing [...], as constitutive of the posthuman subject and elaborate post-anthropocentric forms of ethical accountibility to match it. In my view, posthuman ethics urges to endure the principle of not-One at the in-depth structures of our subjectivity by acknowledging the ties that bind us to the multiple 'others' in a vital web of complex interrelations. This ethical principle breaks up the fantasy of unity, totality and one-ness" (p. 100).

\section{One amongst many: the poetry of Wisława Szymborska}

Keeping in mind this theoretical framework, I will now turn my attention to the poetry of Wisława Szymborska. Briefly focusing on the anthologies View with a Grain of Sand (1995) and Map: Collected and Last Poems (2015), I will try to examine Szymborska's poetry from a posthumanist perspective. My aim is to show in what ways is it possible to perceive in Szymborskian poetics a posthumanist standpoint, as evidenced by compositions that test and display an in-depth revision of the anthropocentric divide between the human and the non-human.

My argument departs from the hypothesis that literary texts can be perceived as imaginary laboratories of both the possible and the impossible, serving as a speculative staging-ground for anthropologies and post-anthropologies of the past, the present, and the future. 1) If we concede that "Literature in particular is an epistemological device for interminably deferring the location of an ultimate perspective from which the being of things could be thought to be known once and for all" (Clarke, 2008, p. 71); 2) if we

furthermore acknowledge that "Literary texts are not merely passive conduits" but rather "actively shape what the technologies mean and what the scientific theories signify in cultural contexts" (Hayles, 1999, p. 21); 3) if we conclude that "While the central role of literature might be questioned in the (post) humanities, the principle of 'fictionality' - the right, in principle, to be allowed to 'say anything' - this fictional freedom of affirmation, this 'as if' (...) cannot be abandoned" (Herbrechter, 2013, pp. 175-176), then it is rather unequivocal how deeply insightful the literary object may be to a posthumanist inquiry.

In what remains of this article, I will try to persuade you that the work of Szymborska elicits such a reading, by claiming that her poems paradigmatically illustrate a 
posthumanist standpoint and put into play the ethical implications of literary configurations of posthumanist subjectivities. Widely recognized as one the most original and compelling European poets of our time, polish writer Szymborska has received international recognition when she was the recipient of the Nobel Prize for Literature in 1996. In awarding the prize, the Academy praised her for "poetry that with ironic precision allows the historical and biological context to come to light in fragments of human reality." Selections of her poems were published in such collections as People on a Bridge (1990), View with a Grain of Sand: Selected Poems (1995), Miracle Fair (2002), Monologue of a Dog (2005), Enough (2012), Here (2013), and Map: Collected and Last Poems (2015). A selection of her short prose pieces was collected in the volume Nonrequired Reading: Prose Pieces (2002).

One of the most striking features of her oeuvre is a powerful poetic alchemy produced by the ironic elegance and the deceptive simplicity of her poetic language. Dodging a lyrical exacerbation and thus resisting the trap of grandiloquence, Szymborsky's poetry shows an irresistible polyphonic quality that is reflected in a set of multiple intersections. Here the trivial intersects with the sublime, and it is this nuanced lightness that has allowed her poetry of the everyday (stemming from Baudelaire) to feed from a variety of themes, whilst not shying away from an existential inquiry.

You will notice at a cursory glance that, "Astonishment", for example, displays Szymborska's ability to think of the of entire world (human, animal, inanimate, intergalactic) as a major interwoven fabric and wonder at its deep interconnectedness:

Why after all this one and not the rest?

Why this specific self, not in a nest,

but a house? Sewn up not in scales, but skin?

Not topped off by a leaf, but by a face?

Why on earth now, on Tuesday of all days,

and why on earth, pinned down by this star's pin?

In spite of years of my not being here?

In spite of seas of all these dates and fates,

these cells, celestials, and coelenterates?

What is it really that made me appear

neither an inch nor half a globe too far,

neither a minute nor aeons too early?

What made me fill myself with me so squarely?

Why am I staring now into the dark

and muttering this unending monologue

just like the growling thing we call a dog?

(Szymborska, 2015, p. 177)

By embracing contingency and relativism, by constantly changing perspectives, Szymborsky's poetry allows us not only to overcome dogmatism, but also to grasp the different nuances of a reality in permanent metamorphosis. And isn't the poet's job to be, as Elias Canetti so eloquently put it in The Conscience of Words (1979), the "keeper of metamorphoses" (Hüter der Verwandlung)?

The question of perspective is here of paramount importance. Szymborska's poems body forth what could be described as a prismatic poetics, since it presents diverse points of view, different perspectives assumed by different lyrical characters, embracing a multiplicity of voices. This focalization (in Genette's terms) allows a diversity of angles, producing a complex configuration of utterances that privilege one particular view over another and which sets us the challenge of discerning in the poem who speaks and who listens, who sees what and how. As stated by Bojanowska: "The open-endedness of her poems on nature, often achieved by pervasive and multidirectional irony and the diversity 
of perspectives that different poems represent, aid her in staying away from 'centrist' dogmatism" (Bojanowska, 1997, p. 220).

I would like to argue that one of the ways in which Szymborska is successful in staying away from this dogmatism is to espouse a posthumanist wordview in which the man is merely one of the many forms of existence, in which, as Deleuze and Guattari put it, man is not "the king of creation, but rather as the being who is in intimate contact with the profound life of all forms or all types of beings" (Deleuze, 1977, p. 4). Szymborska's poetics deploys a thinking of the becoming which rejects any types of linear binarisms and which is formulated on a post-anthropocentric and post-humanist episteme and based on a decentralized and non-hierarchical modes of being-in-the-world.

As we can see, the philosophical nomadism of Braidotti indeed offers a valuable frame of reference to convey this paradigm shift which unfolds into a zoe-centred egalitarianism. In similar vein, Pramod Nayar sponsers what he calls a species cosmopolitanism which constitutes: "the apotheosis of critical posthumanism because of its rejection of easy binaries, whether gender (male/female) or life forms (animal/human, human/plant) or compositional elements (organic/inorganic). Species cosmopolitanism sees all species as always already nodes and intersections along a continuum, full of borrowed characteristics, genes and behaviour. What is enhanced is the dynamics of relations and borrowings [...]. Our origins, like our future evolutions, says the species cosmopolitan, are multiple, diverse and uncertain. Our histories, to use Donna Haraway's favourite word from When Species Meet (2008), are 'entangled'. Species cosmopolitanism and the companion species ideal manifest as the climax of an entire process that, starting with 'different' origin stories, progresses through new configurations of biological citizenship and the theme of a new response-bility toward other species (involving a new ethics of care) and potentiality" (Nayar, 2014, pp. 152153).

By focusing on networks, webs, and intersections, a cosmopolitanism of species thus implies an anti-speciesism and a post-humanist citizenship that brings us to the sharply ethical dimension of this current line of thought. In the remaining time, I would like to allude to a few concrete examples from which a post-humanist vision could be outlined. In this regard, it is particularly noteworthy the poem "A Speech at the Lost-and-Found", which seems to speak of living creatures in mid-evolution, unable to recall "where I left my claws," an aging earth acknowledging the islands that are "lost at sea," a universe who "let several stars go out for good, they can't be traced":

I lost a few goddesses while moving south to north, and also some gods while moving east to west.

I let several stars go out for good, they can't be traced.

An island or two sank on me, they're lost at sea.

I'm not even sure exactly where I left my claws,

who's got my fur coat, who's living in my shell.

My siblings died the day I left for dry land

and only one small bone recalls that anniversary in me.

I've shed my skin, squandered vertebrae and legs,

taken leave of my senses time and again.

I've long since closed my third eye to all that,

washed my fins of it and shrugged my branches.

Gone, lost, scattered to the four winds. It still surprises me how little now remains, one first person sing, temporarily declined in human form, just now making such a fuss about a blue umbrella left yesterday on a bus.

(Szymborska, 2015, p. 176) 
Here the chameleon shifting nature of the speaker (at times, it seems to be the whole universe, at others, a single creature at stages along the winding path from invertebrate to homo sapiens) conjures a polyphony of different viewpoints which perfectly fits with a posthumanist plurality.

Upon reading this delightful poem, one cannot but recall Calvino's dazzling and joyous Cosmicomics, a collection of twelve short stories that, elegantly meshing fantasy and science, desillusion and humor, ironically takes a pseudo-scientific "fact" and builds an imaginative story around it. These whimsical tales of beginning tell the story of the history of the universe, from the big bang, through millenia and across galaxies. It is witnessed through the eyes of "cosmic know-it-all" Qfwfq, an exuberant, chameleon-like figure, who plays marbles with atoms, takes the shape of a dinosaur, of a cell deciding to split for the first time or of a tiny mollusc that comes to grips with the concept of time.

A formally hybrid tour de force which reflects an equally hybrid and polymorphous entity, Cosmicomics fulfills Calvino's dream which he harboured in Six memos for the next millennium, where he compelled us to "Think what it would be like to have a work conceived from outside the self, a work that would let us escape the limited perspective of the individual ego, not only to enter into selves like our own but to give speech to that which has no language, to the bird perching on the edge of the gutter, to the tree in spring and the tree in fall, to cement, to plastic..." (Calvino, 1988, p. 124).

Consider, as well, the poem "Seen from above", in which a subversion of the traditional anthropocentric framing is being enacted:

A dead beetle lies on the path through the field.

Three pairs of legs folded neatly on its belly.

Instead of death's confusion, tidiness and order.

The horror of this sight is moderate,

its scope is strictly local, from the wheat grass to the mint.

The grief is quarantined.

The sky is blue. To preserve our peace of mind, animals die

more shallowly: they aren't deceased, they're dead.

They leave behind, we'd like to think, less feeling and less world,

departing, we suppose, from a stage less tragic.

Their meek souls never haunt us in the dark,

they know their place,

they show respect.

And so the dead beetle on the path

lies unmourned and shining in the sun.

One glance at it will do for meditation -

clearly nothing much has happened to it.

Important matters are reserved for us,

For our life and our death, a death

that always claims the right of way.

(Szymborska, 1996, p. 103)

What is at stake here is the distinction between the experience of death by the nonhuman animal and the same limiting experience on the part of the human. The description of the occurrence does not cause any repulsion to the lyrical subject: after the dispassionate discovery of a dead beetle, we are transported to an ordered and composed universe, stripped of any tragic meaning, where disgust, dismay, or terror find no fit, being instead replaced by order and cleanliness, in a strictly local scope, providing an ever so slightly horrific view. 
Such a description is immediately proven both by a psychological note ("The grief is quarantined."), as by a more objective annotation ("The sky is blue"). This acceptance is related to the ontological disparity that we believe to exist between the dignity of that death and our own extinction: "To preserve our peace of mind, animals die more shallowly: they aren't deceased, they're dead." The poem therefore draws attention to the contrast between the beetle's local death and the supposed superiority of the cosmic death of the human being, underlining and questioning the arbitrariness of such a differentiation.

One could, surely, draw upon Derrida's L'animal que donc je suis (2006). What is at play here is a critical reading of Heidegger's fundamental ontology which, according to Derrida, is, when all is said and done, a more sophisticated form of anthropocentrism. In Heidegger's hierarchical spectrum, the stone is worldless (weltlos), the animal is poor in world (weltarm), whereas the human is world-forming (weltbildend). Derrida would argue with Szymborska that, in classical philosophical discourse, the animal remains a passive object, something which is gazed upon, but does not look back.

In its turn, the poem "Psalm" stages a problematic delimitation of frontiers imposed by the human being, exposing his vain attempt to map what is by nature fluid, porous and incompressible:

\footnotetext{
Oh, the leaky boundaries of man-made states!

How many clouds float past them with impunity;

how much desert sand shifts from one land to another;

how many mountain pebbles tumble onto foreign soil

in provocative hops!
}

Need I mention every single bird that flies in the face of frontiers

or alights on the roadblock at the border?

A humble robin - still, its tail resides abroad

while its beak stays home. If that weren't enough, it won't stop bobbing!

Among innumerable insects, I'll single out only the ant

between the border guard's left and right boots

blithely ignoring the questions "Where from?" and "Where to?"

Oh, to register in detail, at a glance, the chaos

prevailing on every continent!

Isn't that a privet on the far bank

smuggling its hundred-thousandth leaf across the river?

And who but the octopus, with impudent long arms,

would disrupt the sacred bounds of territorial waters?

And how can we talk of order overall?

when the very placement of the stars

leaves us doubting just what shines for whom?

Not to speak of the fog's reprehensible drifting!

And dust blowing all over the steppes

as if they hadn't been partitioned!

And the voices coasting on obliging airwaves,

that conspiratorial squeaking, those indecipherable mutters!

Only what is human can truly be foreign.

The rest is mixed vegetation, subversive moles, and wind.

(Szymborska, 1996, pp. 99-100) 
As usual in Szymborska, the poem opens with the presentation of an initial premise (prooemium) that is later scattered throughout the composition. In this case the use of interjection and exclamation in the inaugural line seeks to highlight the caustic tone of the conceit of the limits imposed by human taxonomies. After the enunciation, the exemplification follows. The lyrical subject relies on the enumeration (numeratio) of natural elements (the clouds, the desert sand, the rocks, the birds, the insects, the octopus) to support the initial claim: however, we should highlight the fact that persuasion does not proceed through categorical statements, but through questions, exclamations and expressive interjections.

After the setting has been laid out, the fifth stanza questions the reader in order to probe (probatio) the validity of the initial statement: "And how can we talk of order overall?/when the very placement of the stars/leaves us doubting just what shines for whom?" The natural elements are seen here as subversives of the cultural convention, as entities that undermine and disrupt the artificial rigidity that characterizes the historically contingent man-made structures and definitions. The final couplet, concise and lapidary, emphasizes human alienation from nature: "Only what is human can truly be foreign./The rest is mixed vegetation, subversive moles, and wind." Here is the way the outcome, almost sententious, strengthens the initial thesis, by pointing out the dichotomy between human perception and natural matter. Ultimately, this poem brilliantly encapsulates the Szymborskian topos of the indiscernibleness of frontiers: between existing and nonexisting, between human and non-human, between visible and invisible, between wakefulness and dream.

In the Szymborskian worldview, the natural world reveals itself alien to the anthropocentric pretensions of human intelection, in such a way that mankind is only one of the many forms of existence. Such an understanding, conductive to a posthumanist paradigm, is fully operative, although at different levels, in several poems by the Polish writer, such as: "View with a grain of sand", "Among the multitudes", "Clouds", "Tarsius", "A speech at the Lost-and-Found", "The silence of plants", "Dinosaur skeleton" or "Conversation with a stone".

\section{Final remarks: poetry or the wounded splendor of which there is no return}

Through irony and paradox, humor and the multiplication of points of view, Szymborska seems to tell us that the human being is only a member of a becoming community, thus appealing to a de-hierarchy of matter (the living and the non-living). To do is to be available to the enigma and to be able, therefore, to live up to the challenges of uncertainty. In her memorable Nobel Prize acceptance speech, titled "The poet and the world", she expresses her fondness of the little phrase "I don't know". She says: "It's small, but it flies on mighty wings. It expands our lives to include spaces within us as well as the outer expanses in which our tiny Earth hangs suspended." "If Isaac Newton," she continues, "had never said to himself 'I don't know', the apples in his little orchard might have dropped to the ground like hailstones, and, at best, he would have stooped to pick them up and gobble them with gusto" (Szymborska, 1998, p. xvi).

She concludes in the form of a gentle admonishment: "Poets, if they're genuine, must also keep repeating 'I don't know.'” (pp. xvi-xvii). Indeed, throughout her life and her work, Szymborska has definitely done so. She has inhabited the heart of astonishment and has emerged intact. Her poetic voice is, essentially, a delicate form of wisdom attentive to the most diverse forms of existence. Hers is a voice that speaks to us of a wounded splendor of which there is no return. 


\section{REFERENCES}

Badmington, N. (2003). Theorizing posthumanism. Cultural Critique 53, 11-27.

Bojanowska, E. M. (1997) Wisława Szymborska: Naturalist and humanist. The Slavic and East European Journal 41.2,199-223.

Braidotti, R. (2013). The posthuman. Cambridge: Polity Press.

Calvino, I. (2010). The complete cosmicomics. London: Penguin Classics.

Calvino, I. (1988). Six memos for the next millennium. Cambridge, Massachusetts: Harvard University Press.

Canetti, E. (1979). The conscience of words. NY: Seabury Press.

Clarke, B. (2008). Posthuman metamorphosis: Narrative and systems. NY: Fordham University Press.

Deleuze, G. \& Guattari, F. (1977). Anti-Oedipus. Capitalism and schizophrenia. Minneapolis: University of Minnesota Press.

Derrida, J. (2006). L'animal que donc je suis. Paris: Galilée.

Genette, G. (1983). Narrative discourse: An essay in method. Ithaca, NY: Cornell UP.

Haraway, D. (2008). When species meet. Minneapolis, London: University of Minnesota Press.

Hayles, K. N. (1999). How we became posthuman: Virtual bodies in Cybernetics, Literature, and Informatics. Chicago: University of Chicago Press.

Herbrechter, S. (2013). Posthumanism: A critical analysis. London/NY: Bloomsbury.

Ligęza, W. (2019). The world under revision: The poetry of Wisława Szymborska. Bern: Peter Lang.

Nayar, P. (2014). Posthumanism. Cambridge/Malden: Polity.

Szymborska, W. (1996). View with a grain of sand. London: Faber and Faber.

Szymborska, W. (1998). Poems, new and collected, 1957-1997. NY: Harcourt Brace.

Szymborska, W. (2015). Map: Collected and last poems. Boston/NY: Houghton Mifflin Harcourt. 